\title{
Neurosyphilis presenting as hypomania
}

\author{
Caroline Jeon MD, Kevin Gough MD MEd
}

Cite as: CMAJ 2021 August 3;193:E1177. doi: 10.1503/cmaj.201892

A 60-year-old man living with HIV presented to his family physician's office with a 3-month history of problems concentrating. For the past 2 weeks, he had noticed a spreading, painless rash involving his trunk, back and extremities (Figure 1). He had a history of crystal meth use disorder, but denied recent substance use. He had been having unprotected sex with casual male and female partners. It was difficult to follow his train of thought; his speech was rapid, he seemed distracted and he described grandiose and unrealistic plans inconsistent with his current situation. He had lost his business and housing. His CD4 T-cell count was 159 (488-1711) cells/ $\mu \mathrm{L}$ or $0.16(0.49-$ $1.71) \times 10^{9} / \mathrm{L}$, and his HIV viral load was $301108 \mathrm{RNA}$ copies $/ \mathrm{mL}$.

Because of his rash and sexual exposure, accompanied by behavioural changes, we suspected infectious neurosyphilis with hypomania. We diagnosed secondary syphilis by a positive treponemal screen with a serum chemiluminescent microparticle immunoassay (CMIA) test, an elevated rapid plasma reagin at 1:64 and a positive Treponema pallidum particle agglutination (TP-PA) assay. Examination of the patient's cerebrospinal fluid, which is also required to diagnose neurosyphilis, showed elevated protein at 1.01 (normal range $0.15-0.45$ ) $\mathrm{g} / \mathrm{L}$ and a positive Venereal Disease Research Laboratory (VDRL) titre of $1: 1$. We treated our patient with intravenous penicillin ( 4 million units every $4 \mathrm{~h}$ for $14 \mathrm{~d}$ ).

The rate of syphilis in Canada has been increasing in the last decade. ${ }^{1}$ Outbreaks often disproportionately affect men who have sex with men, though outbreaks among heterosexual people have been documented in recent years in both urban and rural areas., ${ }^{1,2}$ Neurosyphilis presents more frequently in people with concurrent HIV infection, particularly those with CD4 T-cell counts $<350$ cells $/ \mu \mathrm{L}$ $\left(0.35 \times 10^{9} / \mathrm{L}\right){ }^{3}$ According to retrospective studies, $40 \%$ of patients have ocular involvement, including uveitis, retinal pathology and vision loss. A third of patients have cognitive impairment and a third have neurologic manifestations, such as headache, aphasia, auditory hallucinations and stroke. ${ }^{4,5}$ Psychiatric symptoms vary widely, when they occur. Hypomania is uncommon, affecting fewer

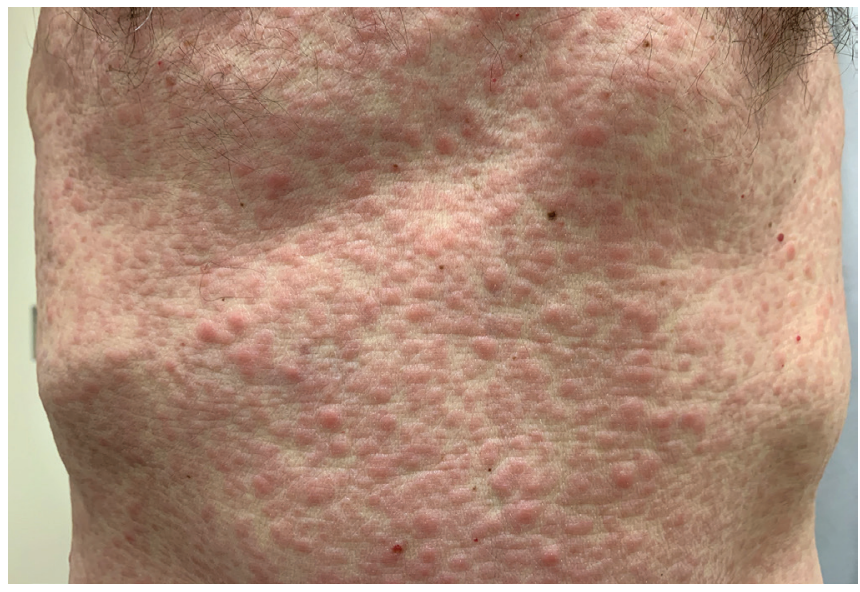

Figure 1: Photograph of the trunk of a 60-year-old man with syphilis. The rash was not painful or pruritic, and extended to both arms and legs bilaterally.

than $10 \%$ of people with neurosyphilis. ${ }^{4}$ Neurological sequelae are often permanent, but our patient made a full recovery after outpatient treatment with intravenous penicillin. ${ }^{3}$

\section{References}

1. Report on sexually transmitted infections in Canada: 2013-2014. Ottawa: Public Health Agency of Canada; 2017. Available: https://www.canada.ca/content/dam/ phac-aspc/documents/services/publications/diseases-conditions/report-sexually -transmitted-infections-canada-2013-14/report-sexually-transmitted-infections -canada-2013-14-eng.pdf (accessed 2020 May 18).

2. Syphilis: key information and resources. Ottawa: Public Health Agency of Canada; 2020. Available: https://www.canada.ca/en/public-health/services/ infectious-diseases/sexual-health-sexually-transmitted-infections/canadian -guidelines/syphilis.html (accessed 2020 Nov. 30).

3. WA Lynn, Lightman S. Syphilis and HIV: a dangerous combination. Lancet Infect Dis 2004;4:456-66.

4. Landry T, Smyczek P, Cooper R, et al. Retrospective review of tertiary and neurosyphilis cases in Alberta, 1973-2017. BMJ Open 2019;9:e025995.

5. Lin L-R, Zhang H-L, Huang S-J, et al. Psychiatric manifestations as primary symptom of neurosyphilis among HIV-negative patients. J Neuropsychiatry Clin Neurosci 2014;26:233-40.

\section{Competing interests: None declared.}

This article has been peer reviewed.

The authors have obtained patient consent.

Affiliations: Department of Family and Community Medicine (Jeon) and Division of Infectious Diseases (Gough), Department of
Medicine, St. Michael's Hospital, University of Toronto, Toronto, Ont.

Content licence: This is an Open Access article distributed in accordance with the terms of the Creative Commons Attribution (CC BYNC-ND 4.0) licence, which permits use, distribution and reproduction in any medium, pro- vided that the original publication is properly cited, the use is noncommercial (i.e., research or educational use), and no modifications or adaptations are made. See: https:// creativecommons.org/licenses/by-nc-nd/4.0/

Correspondence to: Caroline Jeon, caroline.jeon@unityhealth.to 